This is a so-called personal version (author's manuscript as accepted for publishing after the review process but prior to final layout and copyediting) of the article.

Pälli, Pekka, Sorsa, Virpi and Vaara, Eero, 2010. On the force potential of strategy texts: a critical discourse analysis of a strategic plan and its power effects in a city organization. Organization, (17 (6), 685-702.

Researchers are kindly asked to use the official publication in references.

\title{
On the force potential of strategy texts: a critical discourse analysis of a strategic plan and its power effects in a city organization
}

\author{
Eero Vaara \\ Hanken School of Economics, Finland and EMLYON Business School, France \\ Virpi Sorsa \\ Hanken School of Economics, Finland \\ and \\ Pekka Pälli \\ Aalto University School of Economics, Finland
}




\begin{abstract}
Despite increasing interest in the discursive aspects of strategy, few studies have examined strategy texts and their power effects. We draw from Critical Discourse Analysis to better understand the power of strategic plans as a directive genre. In our empirical analysis, we examined the creation of the official strategic plan of the City of Lahti in Finland. As a result of our inductive analysis, we identified five central discursive features of this plan: selfauthorization, special terminology, discursive innovation, forced consensus and deonticity. We argue that these features can, with due caution, be generalized and conceived as distinctive features of the strategy genre. We maintain that these discursive features are not trivial characteristics; they have important implications for the textual agency of strategic plans, their performative effects, impact on power relations and ideological implications.
\end{abstract}

\title{
Keywords
}

critical discourse analysis, deonticity, discourse, force potential, ideology, plan, power, strategy, text, textual agency

Researchers have begun to pay attention to the role of discourse in strategy and strategizing (Ezzamel and Willmott, 2008; Hardy et al., 2000; Laine and Vaara, 2007; Oakes et al., 1998; Phillips et al., 2008; Samra-Fredericks, 2003). However, few studies have examined strategy texts and their characteristics (for exceptions, see Eriksson and Lehtimäki, 1998; Hodge and Coronado, 2006). In particular, we know little of how power is exercised in and through these texts, which is unfortunate given the central role of strategy documents in contemporary organizations and society at large.

Hence, the objective of this article is to examine the characteristic discursive features that explain the power of strategic plans as influential documents. We draw from Critical Discourse Analysis (CDA) (Fairclough, 1995, 2003; Fairclough and Wodak, 1997; van Dijk, 2001; Wodak, 2004), which is a particularly fruitful methodology for understanding the role of texts in strategy processes and in organizational and social struggles. In this spirit, we emphasize that strategy texts are not mere documents representing specific ideas, but that strategy texts have force 
potential (Fairclough, 1992) and textual agency (Cooren, 2004). That is, strategy documents serve several purposes: they communicate socially negotiated meanings, legitimate ways of thinking and action and de-legitimate others, produce consent but may also trigger resistance, and have all kinds of political and ideological effects, some more apparent than others. Consistent with the premise of CDA (Fairclough, 2005; Wodak, 2004), we emphasize the importance of systematic micro-level linguistic analysis as a cornerstone of critical analysis. Thus, this analysis adds to previous strategy studies that have not focused on the crucial textual micro-processes and functions (Hodge and Coronado, 2006; Phillips et al., 2008).

While strategic plans may have powerful effects in all organizations, the public sector provides a particularly interesting setting for our analysis. This is because of the politically and ideologically charged nature of planning and reforms in state and municipal organizations - as studies of community politics (Forester, 1989; Rakow et al., 2003) and New Public Management (Ferlie et al., 1996; Hood, 1991) have illustrated. In particular, recent reforms have tended to either replace bureaucratic values and practices with post-bureaucratic ones (Clegg and Courpasson, 2004, du Gay, 2000, 2003) or strengthen the role of managerialism (Rouillard and Giroux, 2005), which has led to the overall promotion of neo-liberal ideology in public service (Fairclough, 1995, 2003). Importantly for our purposes, these changes have often been linked with the introduction of business sector strategic planning practices into public sector decision-making.

In our empirical analysis, we concentrated on the creation of a strategic plan for local government in Lahti, a city in Finland. We focused on the official strategy document of 2005, but the aim was not only to analyse the textual features of this plan but also to link these characteristics to the production of this plan, as well as its interpretations and use by various actors. For this purpose, we drew from extensive interview, media and other material in this case. Our inductive analysis allowed us to identify and focus on five characteristic discursive features: self-authorization, special terminology, discursive innovation, forced consensus and deonticity. We argue that these discursive features are not trivial characteristics but have important implications for the textual agency of strategic plans, their performative effects and ideological implications. While the specific characteristics and effects are likely to vary depending on the context, we maintain that these features can with due caution be generalized and conceived as distinctive features of the strategy genre. 


\section{Discursive perspectives on strategy}

The discursive aspects of strategy and strategizing have been studied from multiple perspectives. Drawing on critical social analysis, strategy has been conceptualized as an ideologically-laden body of knowledge (Grandy et al., 2007; Knights and Morgan, 1991; Levy et al., 2003; Lilley, 2001). In their influential article, Knights and Morgan (1991) looked at strategy discourse from a genealogical perspective. They traced the roots of strategy discourse in post-war American capitalism and emphasized that its advance was not a 'necessity', but the result of a number of specific developments. In a similar spirit, Levy et al. (2003) proposed a perspective inspired by Critical Theory for further exploration and analysis of the hegemonic nature of strategy discourse and the associated practices. Grandy and Mills (2004) drew on Baudrillard's ideas about simulation and simulacra and analysed the naturalization of this discourse and its effects on practice. According to this view, the strategy discipline and its various models and practices have started to live a life of their own that is disconnected from the (other) reality. Examples of this include 'mission statements', which are believed to be important means for improving organizational performance even though the linkage is vague, to say the least. In a similar vein, by drawing on Wittgenstein, Lyotard and Luhmann, Seidl (2007), suggested that strategy should not be conceptualized as a unified body but rather as fragmented into a multitude of autonomous discourses.

Other research has focused on discursive practices in strategizing (Hardy et al., 2000; Mantere and Vaara, 2008; Vaara et al., 2004). For instance, Hardy et al. (2000) examined a Palestinian NGO organization, where a specific kind of strategic discourse 'took' and legitimated organizational changes. They argued that such processes evolved as circuits of activity, performativity and connectivity. Vaara et al. (2004) studied the discursive practices through which specific strategies such as 'airline alliances' are legitimated and naturalized. In another analysis, Mantere and Vaara (2008) then examined how specific discursive practicesmystification, disciplining, technologization, self-actualization, dialogization and concretization - may impede or promote participation in strategy. Ezzamel and Willmott (2008) in turn analysed how strategic activity was articulated, mobilized and interpreted, and how in particular accounting practices became inbued with strategic significance with implications on what was seen as strategic and what not. Still others have examined the micro-level conversations and rhetoric that constitute everyday strategizing. In particular, Samra-Fredericks (2003, 2004, 
2005) adapted a conversation analysis perspective and explicated a number of analytical routes for fine-grained analysis of the linguistic skills of strategists and the forms of knowledge used by them in strategizing. The essential point was that it is through mundane speech events and various micro-level practices that particular ideas are promoted while others are downplayed and specific voices are either heard or marginalized.

These studies provide many insights that facilitate better understanding of the discursive construction of strategies and strategizing. Yet, at the same time, we seem to know very little about the characteristic discursive features of strategy texts. In particular, there are only a few analyses that focus on strategic plans and the various kinds of discursive and ideological processes and functions at play in these texts. Hodge and Coronado (2006) offer a rare example. In their analysis of the Mexican government's Plan-Puebla-Panama, they illustrated how the discourse on economic reform involved a 'complex' of global capitalist and nationalist discourses and ideologies that was used to promote the opening up of Mexican markets to MNCs based outside of Mexico. Their analysis showed that the form and vocabulary of the document reproduced corporate rhetoric and thus had a fundamental impact on the discursive and ideological struggles. In a similar vein, Laine and Vaara (2007) examined how the mobilization of strategy discourse involved struggles over subjectivity. This study showed how top management can launch a new strategy discourse in order to gain control in and through written and verbal texts, but how this can also trigger discursive and other forms of resistance. These forms of resistance include the middle managers' own strategy discourses, which create room for manoeuvre and cynicism on the part of employees. Phillips et al. (2008) in turn provided an example of how critical discursive analysis can be used to understand the linkage of strategy as a system of shared meaning, strategy as text and talk and strategy as truth. Their analysis of strategic change in a large financial services organization demonstrated how actors adopt various subject positions to accept or resist new discursive identities linked with the narratives of change. In our analysis, we wish to add to this incumbent stream of research by examining the distinctive discursive features and force potential of strategic plans from a CDA perspective.

\section{A CDA approach to strategy texts and their power effects}

CDA is a specific discourse analytic methodology that examines the role played by language in the construction of power relationships and reproduction of domination. Therefore it is a particularly suitable approach for our purposes. Our analysis draws particularly on the work of 
the linguist Norman Fairclough $(1995,2003)$, who has also examined organizational change from a CDA perspective (2005). As mentioned in the previous section, his work has inspired scholars focusing on strategy discourse (Hodge and Coronado, 2006; Laine and Vaara, 2007; Phillips et al., 2008); however, its full potential in the micro-level analysis of texts has still not been realized in this area.

What differentiates CDA from the other critical discursive analyses is the textual orientation: CDA necessitates a close and detailed analysis of texts (Chouliaraki and Fairclough, 1999; Fairclough, 2003). This means that any interpretation of discourse should be based on the text's lexical and grammatical choices, which are placed and considered in the pragmatic context of the text. CDA aims to reveal the social, societal, political and economic assumptions in discourses and texts.

In CDA, discourses are not seen as neutral in terms of their political or ideological content (Fairclough, 1989; van Dijk, 1998). This is sometimes readily observable, while at other times it is the implicit presuppositions or the 'unsaid' elements in the texts, that best reveal underlying assumptions. In fact, texts are capable of circulating and 'hegemonizing' particular ideologies and common sense thinking (van Dijk, 1998). Methodologically, this means that discourses are connected to ideologies through the assumptions embedded in the texts. These assumptions are usually seen as 'triggered' by the linguistic features of text (Fairclough, 2003: 56) and this is why close textual analysis is required in CDA.

Although textual analysis is crucial, proper CDA requires more knowledge of the target phenomena than the text itself can provide. Accordingly, Fairclough (1995) argues that discourses should be simultaneously analysed at three levels: textual (micro-level textual elements), discursive practices (the production and interpretation of texts) and social practice (the situational and institutional context). The first textual level implies close analysis of linguistic structures. The second level of discursive practices brings the community and its behaviour into play; analysis of discourse in this respect is analysis of what people do with texts. Furthermore, at the third level one then focuses on the broader context: how texts and discourses are used in situational and institutional contexts that they both index and construct. With regard to the interplay of the three levels, we agree with Luke (2002: 100), who describes the method of CDA as 'shunting back and forth between microanalysis of texts, using varied tools of linguistic, 
semiotic and literary analysis and the macro analysis of social formations, institutions and power relations that these texts index and construct'.

A full understanding of strategic plans requires that attention is focused on both the genre of strategy texts (conventional aspects of their form and language) and the specific discursive features (articulations of the intended discursive statements) of the text. The analysis of genre is important per se as there is little general understanding of what strategy texts are like and how their very nature impacts their effects. At the same time, there is a need to examine exactly how specific intended discourses are written into the documents, with a special focus on how they are justified.

It is also vital to observe how the text and specific discourses are then interpreted or consumed. This consumption involves recontextualization (Bernstein, 1990; Chouliaraki and Fairclough, 1999; Fairclough, 2003; Thomas, 2003), that is translation of discourses in new contexts. Importantly, when social actors interpret texts, they engage in both less purposive interpretation and more intentional mobilization of discourses for specific purposes. Thus, like production, consumption is a highly political act that may result in the reproduction of initial or intended meanings or lead to very different kinds of views and actions. It is this consumption that ultimately determines whether the 'force potential' of a text will be realized (Fairclough, 1992: $82)$, that is, what the text will accomplish socially: whether and to which extent the textual agency of the strategic text will be actualized, whether it will have performative effects, whether and how it will affect power relations and whether it will reproduce or transform ideological assumptions. To further elaborate on these issues, we now turn to our empirical case.

\section{The case: the official strategic plan in the City of Lahti}

Our research project focused on strategic planning in the City of Lahti. Lahti is located in southern Finland and has a population of about 100,000. The Lahti city administration employs some 6,500 people. The highest political authority in Lahti resides with the City Council, which is elected by the residents every four years. The City Council includes 59 council members; it has partly transferred its powers to the City Board and specific committees and boards. The city administration comprises the Mayor and the directors of each department. As in many other Finnish cities, the role of the city administration has grown over time due to the increasing scope of services offered to people. At the same time, especially since the beginning of the 1990s, Finnish cities have struggled financially. 
Our analysis focused on the strategy text produced in 2005; the original version and its translation can be obtained from the authors. This plan was in many ways a landmark in decision-making in Lahti. In 2003 the City of Lahti elected a new Mayor. At the time the City organization went through organizational restructuring and its administrative bureaus were re-assembled under three departments. Three directors were hired to manage these departments. This meant that when the new City Council assembled in 2005, there were new operative directors in the City's executive group. The new Mayor and his executive group used the 2005 strategy process to launch an extensive change process in the organization. The new strategy included a contested discourse on the concept of 'omavastuu', the direct English translation of which is 'individual responsibility' or 'one's own responsibility'.

Our analysis focused on the official strategic plan and its various versions that we examined following Fairclough's (2003) guidelines. Thus, we zoomed in on the linguistic micro-processes and functions of the text. In addition to examining the textual and discursive features of the plan, we analysed the conditions of its production and the various ways it was put into use, discussed, and referred to in subsequent decision-making and action in the City organization. For this purpose, we made use of extensive ethnographic material gathered on strategic decision-making, including thematic interviews with individuals involved in the process, media texts and even diaries and emails of some individuals. Altogether we interviewed 37 people, including in practice all the central members of the Administration and the key politicians. The idea was to employ a 'storytelling' approach with the use of a semi-structured interview guide. These interviews were crucial in order to understand both the actual planning, revision and implementation processes, but also how different people had experienced these processes. All of the interviews were later fully transcribed.

We also gathered copies of the extensive media coverage associated with the strategy process, as well as debates in which the official strategy was used to legitimate or de-legitimate specific projects or changes. Altogether, this material amounted to 193 media texts. Furthermore, we obtained a few personal diaries kept by people participating in the strategy process, as well as the personal emails of some decision-makers. These personal comments provided interesting additional material, illuminating people's genuine personal experiences at various stages of the strategic planning process. All this material helped us to go beyond the final version of the official strategy text, to understand what lay behind specific ideas and expressions, and how central parts of the document were constructed, negotiated and put into use in various arenas. 
Our inductive analysis proceeded in an abductive manner (Wodak, 2004); we went back and forth between our theoretical ideas and empirical analyses to create an increasingly elaborate understanding of the various discursive features that seemed to explain the power effects of the strategic plan. In our analysis, we eventually narrowed the focus to five central discursive features: self-authorization, special terminology, discursive innovation, forced consensus and deonticity. These concepts will be elaborated further in the following sections.

This kind of analysis involves methodological challenges. Discursive and textual characteristics are complex objects to describe and analyse. In particular, it is difficult to place specific elements into their broader context. However, our 'triangulation' strategy - a constant effort to compare our interpretations of the strategic plan with other information gathered-helped to deal with these challenges. This kind of analysis is necessarily interpretative and subjective, which can lead to one-sided representations and conclusions. However, working in a team of three researchers with different backgrounds and meeting with a number of local people representing different professional and political perspectives helped to put things into perspective. Finally, it should be noted that the reporting of this analysis is challenging language-wise: the actual analysis was conducted in Finnish, but the main results were translated into English for this article. Although meanings and nuances were unavoidably lost in such translations, the richness of the material allowed us to deal with specific problems by constantly comparing several examples.

\section{Self-authorization as a basis for textual agency}

A characteristic feature of this strategic planning process was self-authorization. The strategic process began in the fall of 2004 when the new Mayor and his executive group got together to negotiate how the 2005 strategy process should be conducted. In September 2004, they started to convene once a month, together with two consultants that were specialists in the training and consultancy of public management. According to the interviews and documentary material, this work was set up as a 'priority', meant to 'give new direction to the City', with the objective to 'provide an overall frame for decision-making'. Consequently, the new strategy was from its onset defined as a particularly authoritative directive text, which can be seen as a prerequisite for its textual agency in this context (Cooren, 2004).

The final document was self-authorizing in nature, which can be seen as a typical characteristic of the strategy genre. In a sense, the strategy communicated its own importance, especially in the 
case of the metatext, i.e. the sentences describing and defining the purpose and objectives of the plan. The most obvious examples were statements such as the following:

Strategy is a central tool for leading a city.

The vision, together with the entire strategy, is a municipal council tool for pointing out the direction in which the council wants the city to be developed.

However, this self-authorization was also frequently expressed in more subtle forms in various parts of the plan, as in the extract below:

New management and operational systems will facilitate strategy implementation. Ownership management and buyer skills will be improved. The role and position of elected officials and their confidential posts will be reappraised to support strategy implementation.

Central here are the propositions that refer to 'strategy' and 'following strategy'. In the first sentence, 'new management and operational systems will facilitate strategy implementation' creates an order where strategy comes first and other things are then seen as instruments for implementation of the strategy. In the third sentence, the effect is more direct and fundamental: the role of elected officials (including the City Council!) is to be adjusted to the requirements of the strategy. Such statements had fundamental implications for the power relations of the various actors, in particular strengthening the position of the administration vis-à-vis the politicians.

Overall, the effects of the strategic plan were most visible in the ways in which it was used as a reference point in subsequent decision-making and the legitimation of actions. The new strategy in particular served to justify a far-reaching rationalization of health care services - which according to our interviewees would not have been possible without the new strategy. As a key manager put it:

In order to be able to set the criteria, which enabled the cuts and prioritization, we had to have a strategy behind it. (Director)

A seasoned politician put it as follows:

I have the feeling that when someone on the City Board introduces proposals, they are based on the City's strategy. Like I said earlier, the administration has internalized this quite well. You know, they seem to like it that they have something to lean on when things get tough with the councilmen: they can say that they are just complying with what has already been decided. So I definitely feel that it guides what is happening. (Politician) 
Thus, the strategy document became a textual agent, an actor that had the capacity to produce action from a distance (Cooren, 2006; Cooren et al., 2007; Robichaud, 2006). This textual agency was, however, dependent on its mobilization in discussion by the administration and other stakeholders.

\section{Special terminology: implications for knowledge and authority}

Another distinctive feature of the strategic plan was the use of distinctive strategy terminology: the shared and specified lexicon known by strategy specialists as a special discursive community (Swales, 1990). This vocabulary facilitated but also constrained the conventions associated with how to discuss strategies, how to write up the strategies, and how to interpret the final text of the document.

The strategic planning process followed the general models of strategic planning and - crucially for our purposes - was structured by strategic concepts and vocabulary. Strategy concepts and their appropriate interpretation were taught by strategy consultants in strategy seminars organized for the participants in the strategic planning process. The same material (slides, definitions, examples, etc.) was also used in the various meetings where the strategy was discussed and written. In particular, terms such as SWOT, change factors, scenarios, vision, strategic goals and critical success factors became central concepts structuring the conversations. One of the participants described the process as follows:

Well, we used quite a lot of time to reflect on the basic information and figure out what I would call gimmicking with words. In other words, we pondered the strategic goals and things like which concepts we should use to express them. (Director)

This focus on strategy language may appear trivial at first glance, but it had far-reaching implications in this context. In particular, this language affected the power positions of the various decision-makers, because some of the people mastered this discourse better than others due to their background, education or exposure to strategic management (for similar observations, see Oakes et al., 1998; Samra-Fredericks, 2003). For example, a participant reflected on the difficulties posed by the 'strategy jargon' in his personal diary:

Words of foreign origin such as 'scenario' hamper understanding and commitment. It would be important to be more precise and explain what the words mean. (Administration) 
The final text relied extensively on strategy concepts. In particular, these terms provided important rhetorical structures for the document. 'External' and 'internal strengths' and 'internal challenges', 'threats' and 'opportunities' were key concepts that reproduced the structure of a SWOT-analysis. Terms such as vision and mission were used to define the ultimate objectives of the City and its services. This was also the case with 'Critical Success Factors' and 'Balanced Scorecard', which played a central role in the structure of the latter part of the document. Importantly, such structures brought with them corporate strategy-type conventions that forced the participants of the strategic planning process to make sense of the City's future with a corporate strategy type of logic, along with its ideological implications (for analogous findings, see Hodge and Coronado, 2006).

The importance of an appropriate understanding of strategy concepts was emphasized in the final text, which included a great deal of explanations and definitions:

Strategic objectives make things more clear and concrete, they open up the vision. They lay out what is meant by the vision, what is going to change and in what direction development should be channelled.

Critical success factors are core issues or states of affairs whose success or failure affects the success of a public organization decisively over a long period of time.

In both extracts there is a clear explanatory mood, which is seen in the generic claims about strategy concepts and attempts to give sense to them. Thus, the text seems to be directed at a reader who does not necessarily understand strategy language or the reasoning related to this particular strategy. These linguistic articulations are significant in terms of the interpersonal positioning that constitutes social and political power relations. In simple terms, this means that the authors are constructed as 'experts' with related 'expert power' while the readers need an explanation of what the text essentially means (Bourdieu, 1991). In the strategy context, the implication is the construction of a pedagogic power relationship where the propositions made are very difficult to challenge by those who have not mastered strategy discourse (Oakes et al., 1998; Samra-Fredericks, 2003).

This extensive and systematic use of strategic vocabulary was generally interpreted positively by the administration that had searched for ways to make discussion and decision-making 'more focused' and 'systematic'. However, many politicians expressed reservations about the complicated terms and their meanings. The following is a typical comment from a leading politician: 
It is quite hard, you know, for a politician to explain how things are taken care of to a city resident. We have delegated power to operative directors and departments ... And then when you think how these things appear to residents when we talk about these fine concepts and say 'We don't know. It's here'. [Taps on the strategy document] So what is our credibility in the long run? Now if we go on like this it will be the executive group that runs the City like a firm. And I don't think it should be like this. (Politician)

\section{Discursive innovation: new buzzwords and their implications}

A third crucial feature of the strategic plan were 'discursive innovations', that is statements that crystallized key ideas about new priorities for the City's strategic decision-making. In this case, the most central new idea was the discourse on 'individual responsibility'. The strategy group not only decided to launch an extensive change process in the city organization but also to promote a new kind of thinking among the residents of Lahti. One of the Directors - a key architect of the new strategy—described the crystallization of this discourse as follows:

I guess I am to blame for the emphasis on individual responsibility in this project. I have seen in my previous work that cities don't have the economic resources needed to keep all the promises that have been made to its citizens. That is one [factor]. If we refer to these welfare services as a wide concept, demand for them on the part of citizens will continue to grow ... In this matter I have often referred to the thinking of [a prominent professor of health policy and management] ... Another [factor] is the [individual] responsibility for financing the services-what [services] people are purchasing for themselves. That percentage has to be increased ... in addition to responsibility for one's own wellbeing and health. (Director)

As this quote illustrates, the new discourse focused on two things: the need to improve the financial situation of the city and to make the residents adopt a more active role in seeking and financing alternative services. In the strategic plan, this theme of individual responsibility was then introduced and justified with compelling rhetorical choices:

The City of Lahti will be forced to change the basic premise of its service offerings in order to accommodate growing demand and take into account increasing financial constraints. This means that the city will no longer be able to meet all of the needs of its residents. In the future, the city must encourage people to take more responsibility for their personal well-being and the well-being of their loved ones.

In the offering of services, emphasis is placed on variety, the availability of choice and individual responsibility.

Promoting well-being requires a new way of thinking. In the future, a larger responsibility for well-being will shift to the people of Lahti themselves and their community. It is in fact a cultural change, a change of attitude, with the intention of 
strengthening the will of the people of Lahti to support and help each other when the need arises.

In the first extract, the first sentence mentions 'the basic premise of its service offerings'. This nominal phrase is given meaning in the next sentence: the central meaning of the basic premise is to be 'able to meet all of the needs of its residents'. This implies that the City has previously promised to meet all its residents' needs and actually done so. Moreover, it is suggested that this has been a responsibility carried out by the City, but that things will have to change in the future. This transfer of responsibility is thus framed as a strategic innovation that involves dramatic changes in the social welfare system, as articulated in other parts of the strategy text.

The argumentation follows the logic of compulsion: the verbal phrase 'forced to change' expresses deontic modality; the City is under an obligation to change its service supply and the obligation is external or caused by external factors (we will come back to deonticity below). The same rhetoric is backed up by the nominalizations 'growing' and 'tightening'. The inevitability of change is constructed in a declarative mood, for example in the following sentences 'will no longer be able to meet all of the needs of its residents' (first extract) and 'a larger responsibility for well-being will shift to the people of Lahti themselves' (third extract). These formulations help to factualize the state of affairs, and they can be read as promises, threats or ordersdepending on the interpretation.

This text also included rather manipulative rhetorical constructions, such as the following:

Several factors that clearly create future opportunities for the city include the increasing sense of responsibility the residents of Lahti feel for themselves and each other.

The point here is that the SWOT analysis type of reasoning is turned into an argument promoting the new strategy. It is interesting that this sense of responsibility was represented as 'clearly' one of those factors that will create future opportunities. This was an issue that caused much debate in Lahti, it was not an accepted fact as it is presented here. In fact, our interviewees mentioned several times that one of the problems with the strategy text was that skillful rhetoric was used in ways that created 'wrong impressions' and 'simplified the situation'. ${ }^{1}$ Furthermore, in the text this point was not balanced by any reflection on the negative effects that more limited service offerings might have, for example on those who are not able (financially or otherwise) to take more responsibility for their own well-being. 
The discourse of 'individual responsibility' was launched as a new way of thinking about services that the city offers, along with their organization and financing. However, the strategy text also led to other kinds of interpretations when the idea of individual responsibility was discussed after the launching of the new strategy. The following are typical examples of different interpretations:

Well, in that sense we are pioneers in strategic thinking regarding this issue [individual responsibility]. In the strategies of other cities, they haven't dared to say that the residents have to take on more individual responsibility. Now even the state level has woken up to the issue: 'yeah, maybe it has something to do with the residents or citizens themselves taking care of these things'. You know this term 'individual responsibility' has clearly started to take on in the Ministry of Social Affairs and Health and such places. (Administrative official)

It is also a kind of ideological choice, or I think it is, that we are changing the city organization from a kind of caretaking society where everyone is taken care of and society is responsible for taking care of everyone, towards ... I don't know too much about American society but, at least, it is strikes me that we are moving towards the American way, where everyone takes care of themselves. Like it would no longer be society's responsibility to take care of its members. (Politician)

Whilst the interviewee in the first quote articulates the discourse of 'individual responsibility' as an innovation, the second quote shows a very different way of looking at its effects. Thus, 'individual responsibility' was at the centre of an ideological struggle. In very concrete terms, the new discourse implied a shift from a Nordic welfare regime towards a neo-liberal market economy that some people supported and others resisted. In several instances, the strategy text loosened welfare engagements and reduced the importance of the values and institutions contained in the traditional Finnish and Nordic model, thereby moving towards a neo-liberal order. However, people interpreted its actual meanings and implications in very different ways.

\section{(Forced) consensus: formal closure and its implications}

A fourth intriguing discursive feature was the focus on 'forced consensus', that is the need to reach some degree of unanimity or alignment for the strategic plan. Although there were radical differences of opinion between individuals, political parties, and between elected leaders and civil servants concerning the new 'individual responsibility' discourse, these disagreements are not apparent in the text. Instead, the final text serves as formal closure of the discussion (for similar observations, see Iedema, 1999).

The pressure to reach consensus was probably most clearly visible in the case of 'individual responsibility'. When this new discourse was brought up, it was initially strongly resisted. How- 
ever, the negotiations eventually led to new formulations of the text, as well as to novel interpretations of what 'individual responsibility' actually meant. After a long negotiation process with different interest groups, this notion of 'individual responsibility' maintained its place as a central part of the strategy text. One reason this happened was that the politicians in particular were able to link 'individual responsibility' with 'activeness', that is with being an active member of the community, which was on the whole seen as positive. Another reason for why the discourse was finally accepted was that the actual textual passages were 'sweetened' so that enough political constituencies could support the whole document.

The final document reflects a strong unanimity of opinion. In fact, this unanimity is even explicitly emphasized in several instances. For example, the text for the 'Strategic Goal Number One' reads as follows:

The inhabitants of Lahti, its political and civil servant leadership, and its employees will have a common, realistic understanding of the city's opportunities and the expectations related to them.

This kind of unanimity adds to the power of the strategic plan, as it supposedly represents the agreed upon objectives of key decision-makers. In this case, the crucial issue was that the City would no longer be the only actor seen as responsible for providing welfare services and that welfare was now to a large extent also the obligation of the people themselves. This was most evident in terms of the implications of 'individual responsibility'. Consider the following extract:

Services will not be provided according to production capacity, but will be based on real customer need.

The articulation of the extract refers to two alternative arguments: services are organized either 'according to production capacity' or 'based on real customer needs'. The use of negation in the first sentence and the word 'real' in the second one leads to an interpretation that the services are or have been organized on the basis of a false logic that now has to be changed. This new logic is indeed fundamentally different from the previous one: it implies a shift from a Nordic welfare state model towards a neo-liberal ideology.

Not surprisingly, the individual responsibility discourse became the most contested issue in the interpretation of the strategic plan. Many people were happy about the decisive new strategy and the guidelines it provided. However, others felt that the discourse contained ideas and ideological 
implications that were not spelled out, but skillfully written into the text under the auspices of consensus without a fuller discussion of their exact meaning or implications. Two of them put it as follows in our interviews:

It includes a lot of value discussion that has not been spelled out. (Director)

There was a strong sense that we were being fooled. Sentences were included that promoted privatization even more. (Politician)

Thus, the forced consensus was at times challenged by critical readings of the document and the way it was crafted.

\section{Deonticity: from declarative statements to imperatives}

Finally, a fifth characteristic discursive feature was the deontic orientation of the final document, i.e. its obligatory and imperative nature. Deonticity deals with a combination of a semantic component meaning 'so-be-it' and necessity (Lyons, 1977: 823-830). According to this view, deonticity involves a reference to a future state and is connected with intention. Interestingly, the strategic planning process did not start with imperatives in mind, but rather moved from futureoriented scenario analysis toward more precisely stated objectives. A key manager described this preparation as follows:

We began as is usually the case with environmental analysis [...] and then moved on to purpose and vision, objectives and strategic goals and critical success factors, and so on. It was very much like a typical process in corporations.

Although the grammatical sentence types in the strategic plan document are at first glance purely declarative, the grammatical mood becomes different when we take into consideration the purpose of the text, which is to guide future action. This means that a grammatically declarative statement turns into an imperative one. Halliday (1994: 354-367) calls these kinds of shifts metaphors of mood, as a sub-class for grammatical metaphors. Consider the following examples:

The city's finances will strengthen to the extent that the contribution margin will suffice to cover all net investments and even pay off the debt.

Strengthening the income base, along with changes in the service structure and process, will assist in balancing the city's budget. Taxation will not be relied on as the primary agent for balancing the budget. The city's ownership policy is profitable, and the required return on this capital is obtained. 
The point is that when the text is considered as a directive text that provides guidelines to be followed, these kinds of seemingly declarative statements are interpreted as imperatives. Thus, declarations such as 'finances will strengthen', 'will assist in balancing the city's budget', 'taxation will not be relied on' and 'ownership policy is profitable' become directive obligations for the administration and other decision-makers.

The implications of deonticity can be seen as performative effects of the strategy. This is how one of the key Directors summarized the implications:

It [the strategy] has clearly defined the economic framework, allowing us to cut personnel and modify operations so we could manage with fewer employees. It also assisted with changes in payment and rate systems. We had to re-think our operations to determine how we could hike up prices and rates and also cut expenses linked to those operations. We had to figure out how assignments would be arranged and what operations and services had to be omitted. (Director)

Note too how strategy is referred to as an agent; it is the strategy, which has 'clearly defined the economic framework'. Another Director put it as follows:

Different service structures have been reduced, e.g. care subsidies for close relatives. I mean ... in spite of everything, it is essential that we scale back the existing service structure in Lahti. And perhaps the political system didn't understand. (Director)

Such quotes are illuminating examples of the strategy text's realized force potential. The interviewees' interpretations of the effects of the strategy indicate the use to which the strategy was put in the City organization of Lahti. In essence, as shown above, the strategy text can be considered an order to downsize the service structure. However, in the second quote the comment 'and perhaps the political system didn't understand' points to the fact that there was a struggle over the exact meanings of the strategy text. The contradictions in the text were not fully resolved, as some people continued to resist straightforward interpretations when the text was used as a basis for subsequent decision-making. This is not surprising considering what we know about the production of the text; in particular how politicians in specific stages felt bypassed in decisionmaking. Thus, the deontic effects of the text could at times be resisted by alternative interpretations.

\section{Conclusion}

Although recent studies have adopted critical discursive perspectives on strategy (Hodge and Coronado, 2006; Laine and Vaara, 2007; Phillips et al., 2008), there is a lack of understanding of 
the linguistic micro-processes through which specific discourses are written into strategy texts and how their power effects come into being. Hence, the objective of this article has been to examine the discursive characteristics that help to explain the power strategic plans as influential directives. Table 1 summarizes our main findings.

In our analysis we have focused on the force potential of strategic plans (Fairclough, 1992), involving its textual agency, performative effects, impact on power relations and ideological implications. While there is much more to this issue that we have been able to highlight in this analysis, our CDA perspective at least shows that such force potential relates on the one hand to the genre itself and on the other to specific discursive choices. At the same time, as our case vividly illustrates, it is the crucial role of the subsequent mobilization of the discourse that ultimately determines whether the text will have textual agency (Cooren, 2004) and specific power implications. Thus, the power effects of texts must in the end be linked with the production and consumption of the texts (Hardy and Phillips, 2004) and the related 'circuits of power' (Clegg et al., 2006).

We believe that this analysis has important implications for our understanding of the role of language in strategy. In particular, it helps to better comprehend the specific micro-level discursive and textual processes through which strategy documents impact strategizing and decision-making in general. Thus, this analysis adds to the previous literature on the discursive underpinnings of strategy (Knights and Morgan, 1991), the mobilization of strategy discourse (Hardy et al., 2000) and also its enactment in conversations (Samra-Fredricks, 2003). In particular, our analysis complements the recent analyses adopting critical discursive perspectives of strategy and strategizing (Hodge and Coronado, 2006; Laine and Vaara, 2007; Phillips et al., 2008) by focusing attention on the discursive underpinnings of the power of strategic plans as influential texts. The crucial point is that this kind of analysis makes it possible to see how the institutionalized use of strategy language has implications: some of these emerge from the genre itself while others derive from situation-specific choices. In any case, one thing is certain: strategy documents should not be treated as just any texts, but understood as powerful devices through which specific objectives, values and ideologies — and not others - are promoted and legitimated. Importantly, some of these effects are apparent, but many others easily pass unnoticed. 
Table 1. Discursive characteristics as the basis of the force potential of strategic plans

\begin{tabular}{|c|c|c|c|c|}
\hline & $\begin{array}{l}\text { Conditions of } \\
\text { production }\end{array}$ & $\begin{array}{l}\text { Textual } \\
\text { characteristics }\end{array}$ & $\begin{array}{l}\text { Observations on } \\
\text { consumption }\end{array}$ & Power effects \\
\hline $\begin{array}{l}1 \text { Self- } \\
\text { authorization }\end{array}$ & $\begin{array}{l}\text { Emphasis on the } \\
\text { importance of } \\
\text { strategy work }\end{array}$ & $\begin{array}{l}\text { Frequent } \\
\text { references to the } \\
\text { authoritative role } \\
\text { of strategy } \\
\text { (especially in } \\
\text { metatext but also } \\
\text { in other parts of } \\
\text { the document) }\end{array}$ & $\begin{array}{l}\text { The textual agency } \\
\text { of the strategic } \\
\text { plan as an } \\
\text { authoritative text is } \\
\text { realized by using it } \\
\text { as a reference } \\
\text { point in } \\
\text { subsequent } \\
\text { decision-making } \\
\text { and legitimation of } \\
\text { action }\end{array}$ & $\begin{array}{l}\text { Prioritization of } \\
\text { strategy as the } \\
\text { overall guideline } \\
\text { for decision- } \\
\text { making and action } \\
\text { Use of the strategic } \\
\text { plan to legitimate } \\
\text { or resist } \\
\text { subsequent } \\
\text { decisions or } \\
\text { actions }\end{array}$ \\
\hline $\begin{array}{l}2 \text { Special } \\
\text { terminology }\end{array}$ & $\begin{array}{l}\text { Strategic concepts } \\
\text { and terminology as } \\
\text { a basis of } \\
\text { planning, } \\
\text { conversations and } \\
\text { writing of the } \\
\text { document }\end{array}$ & $\begin{array}{l}\text { Use of strategy } \\
\text { concepts as central } \\
\text { rhetorical } \\
\text { structures }\end{array}$ & $\begin{array}{l}\text { Different } \\
\text { interpretations } \\
\text { depending on the } \\
\text { mastery of strategy } \\
\text { vocabulary and } \\
\text { agreement with the } \\
\text { ideals of corporate } \\
\text { strategy }\end{array}$ & $\begin{array}{l}\text { Reproduction of } \\
\text { the ideals and } \\
\text { ideologies of } \\
\text { corporate strategy } \\
\text { Implications on the } \\
\text { power relations of } \\
\text { social actors } \\
\text { depending on their } \\
\text { knowledge and } \\
\text { ability to use } \\
\text { strategy concepts } \\
\text { and vocabulary }\end{array}$ \\
\hline $\begin{array}{l}3 \text { Discursive } \\
\text { innovation }\end{array}$ & $\begin{array}{l}\text { Focus on specific } \\
\text { discursive } \\
\text { statements that } \\
\text { spell out the } \\
\text { priorities }\end{array}$ & $\begin{array}{l}\text { Focus on the new } \\
\text { discourse } \\
\text { Compelling } \\
\text { justification of the } \\
\text { new discourse }\end{array}$ & $\begin{array}{l}\text { Different } \\
\text { interpretations } \\
\text { depending on } \\
\text { agreement with the } \\
\text { new discourse and } \\
\text { its implications }\end{array}$ & $\begin{array}{l}\text { Performative and } \\
\text { ideological } \\
\text { implications } \\
\text { stemming from the } \\
\text { new discourse }\end{array}$ \\
\hline $\begin{array}{l}4 \text { Forced } \\
\text { consensus }\end{array}$ & $\begin{array}{l}\text { A need to reach a } \\
\text { degree of } \\
\text { unanimity and } \\
\text { alignment in } \\
\text { strategy work }\end{array}$ & $\begin{array}{l}\text { Explicit and } \\
\text { implicit references } \\
\text { to consensus and } \\
\text { its use as } \\
\text { authorization of } \\
\text { statements }\end{array}$ & $\begin{array}{l}\text { Reproduction of } \\
\text { consensus in } \\
\text { subsequent } \\
\text { discussion } \\
\text { Challenging of the } \\
\text { consensus by } \\
\text { critical comments }\end{array}$ & $\begin{array}{l}\text { Consensus as } \\
\text { authorization for } \\
\text { the implementation } \\
\text { of the strategic } \\
\text { ideas }\end{array}$ \\
\hline 5 Deonticity & $\begin{array}{l}\text { Declarative } \\
\text { statements as an } \\
\text { explicit goal in } \\
\text { preparation of the } \\
\text { document }\end{array}$ & $\begin{array}{l}\text { Declarative- } \\
\text { imperative mood } \\
\text { (shifts from } \\
\text { declarative to } \\
\text { imperative mood } \\
\text { when the purpose } \\
\text { of the text is taken } \\
\text { into account) }\end{array}$ & $\begin{array}{l}\text { Reproduction of } \\
\text { imperatives in } \\
\text { subsequent } \\
\text { discussion and } \\
\text { decision-making } \\
\text { Challenges coming } \\
\text { from critical } \\
\text { interpretations }\end{array}$ & $\begin{array}{l}\text { Performative } \\
\text { effects resulting } \\
\text { from the } \\
\text { imperatives }\end{array}$ \\
\hline
\end{tabular}

Discursive practices are a crucial part of the social practices constituting strategy and strategizing. By analysing the key role of texts and related discursive practices from a critical perspective, our analysis contributes to the broader 'strategy-as-practice' stream of research (Jarzabkowski, 2005; 
Whittington, 2006) that has been lacking in such analyses. In fact, precisely these kinds of critical discursive examinations have been called for in the recent debate around 'strategy-as-practice' (Carter et al., 2008a, 2008b; Jarzabkowski and Whittington, 2008; McCabe, 2010).

We also think that the analysis has implications for discussions regarding community planning and politics (Forester, 1989; Rakow et al., 2003) and New Public Management (du Gay, 2000; Ferlie et al., 1996; Hood, 1991). While previous studies provide insightful analyses of power and ideology in public sector reform (Forester, 1989; Norton and Sadler, 2006; Rakow et al., 2003), our analysis adds to this literature by focusing on the power of official strategy documents as vehicles through which specific social and societal changes are promoted, legitimized and naturalized in the 'post-bureaucratic era'. The point is that these texts do not only promote- or in some cases challenge - particular kinds of reforms, but also determine and redefine the power and subjectivity of various social actors (Thomas and Davies, 2005). As the Lahti case demonstrates, this is especially the case with respect to decision-making power and participation in strategic decision-making.

We believe that most of the discursive practices that we have highlighted in our analysis play a central role in other strategy plans as well. However, we wish to emphasize that any serious CDA of specific strategic plans should take the context seriously and focus on highlighting the central textual choices that make a difference in that setting. It would therefore be important to study strategy texts in other institutional organizational, national and cultural contexts and to compare the findings. This would lead to a better understanding of not only the strategy texts per se, but also the conventions in writing and editing strategy documents and the various ways in which power and ideological struggles are played out in and through these texts.

\section{Note}

1 The participants of the strategic planning group felt that all people did not really understand the implications of the text that they were discussing. The following diary entry of an administrator is revealing: 'Again the comments focused on stylistic issues. I'm afraid that no one understands that we are moving towards a decrease in the level of service'. 


\section{References}

Bernstein, Basil (1990) Class, Codes and Control, Volume 4: The Structuring of Pedagogic Discourse. London: Routledge.

Bourdieu, Pierre (1991) Language and Symbolic Power. Cambridge: Polity Press.

Carter, Chris, Clegg, Stuart and Kornberger, Martin (2008a) 'Strategy as Practice?', Strategic Organization 6(1): 83-99.

at Hanken School of Economics on December 15, 2010 org.sagepub.com Downloaded from 700 Organization 17(6)

Carter, Chris, Clegg, Stuart and Kornberger, Martin (2008b) 'S-A-P Zapping the Field', Strategic Organization 6(1): 107-12.

Chouliaraki, Lilie and Fairclough, Norman (1999) Discourse in Late Modernity: Rethinking Critical Discourse Analysis. Edinburgh: Edinburgh University Press.

Clegg, Stewart and Courpasson, David (2004) 'Political Hybrids: Tocquevillean Views on Project Organizations', Journal of Management Studies 41(4): 525-47.

Clegg, Stewart, Courpasson, David and Phillips, Nelson (2006) Power and Organizations. London: Sage.

Cooren, Francois (2004) 'Textual Agency: How Texts Do Things in Organizational Settings', Organization 11(3): 373-93.

Cooren, Francois (2006) 'The Organizational World as a Plenum of Agencies', in F. Cooren, J. R. Taylor, E. J. Van Every (eds) Communication as Organizing: Empirical and Theoretical Explorations in the Dynamic of Text and Conversation, pp. 81-100. Mahwah, NJ: Lawrence Erlbaum.

Cooren, Francois, Matte, Frédéric, Taylor, James R. and Vasquez, Consuelo (2007) 'A Humanitarian Organization in Action: Organizational Discourse as an Immutable Mobile', Discourse and Communication 1: 153-90.

du Gay, Paul (2000) In Praise of Bureaucracy: Weber, Organization and Ethics. London: Sage. du Gay, Paul (2003) 'The Tyranny of the Epochal: Change, Epochalism and Organizational Reform', Organization 10(4): 663-84.

Eriksson, Päivi and Lehtimäki, Hanna (1998) 'Strategic Management of the Local Information Society. A Constructionist Perspective on the Production and Evaluation of Strategy Documents', Administrative Studies 4: 290-301.

Ezzamel, Mahmud and Willmott, Hugh (2008) 'Strategy as Discourse in a Global Retailer: A Supplement to Rationalist and Interpretive Accounts', Organization Studies 29(2): 191-217.

Fairclough, Norman (1989) Language and Power. London: Longman.

Fairclough, Norman (1992) Discourse and Social Change. Cambridge: Polity Press. 
Fairclough, Norman (1995) Critical Discourse Analysis: The Critical Study of Language. London: Longman.

Fairclough, Norman (2003) Analysing Discourse: Textual Analysis for Social Research. London: Routledge.

Fairclough, Norman (2005) 'Discourse Analysis in Organization Studies: The Case for Critical Realism', Organization Studies 26(6): 915-39.

Fairclough, Norman and Wodak, Ruth (1997) 'Critical Discourse Analysis' in T. van Dijk (ed.) Discourse as Social Interaction, pp. 258-84. London: Sage.

Ferlie, Evan, Ashburner, Lynn, Fitzgerald, Louise and Pettigrew, Andrew (1996) New Public Management in Action. Oxford: Oxford University Press.

Forester, John (1989) Planning in the Face of Power. Berkeley: CA: University of California Press.

Grandy, Gina and Mills, Albert J. (2004) 'Strategy as Simulacra? A Radical Reflexive Look at the Discipline and Practice of Strategy', Journal of Management Studies 41(7): 1153-70.

Halliday, M. A. K. (1994) An Introduction to Functional Grammar, 2nd edn. London: Arnold.

Hardy, Cynthia, Palmer, Ian and Phillips, Nelson (2000) 'Discourse as a Strategic Resource', Human Relations 53(9): 1227-48.

Hardy, Cynthia and Phillips, Nelson (2004) 'Discourse and Power' in D. Grant, C. Hardy, C. Oswick and L. Putnam (eds) The Sage Handbook of Organizational Discourse, pp. 299-316. London: Sage.

Hodge, Bob and Coronado, Gabriela (2006) 'Mexico Inc.? Discourse Analysis and the Triumph of Managerialism', Organization 13(4): 529-47.

Hood, Christopher (1991) 'A Public Management for All Seasons', Public Administration 69(1): $3-19$.

Iedema, Rick (1999) 'Formalising Organizational Meaning', Discourse and Society 10(1): 49-65. Jarzabkowski, Paula (2005) Strategy as Practice: An Activity Based Approach. London: Sage. at Hanken School of Economics on December 15, 2010 org.sagepub.com Downloaded from Vaara et al. 701

Jarzabkowski, Paula and Whittington, Richard (2008) 'A Strategy-as-Practice Approach to Strategy Research and Education', Journal Of Management Inquiry 17(4): 282-86.

Knights, David and Morgan, Glenn (1991) 'Strategic Discourse and Subjectivity: Towards a Critical Analysis of Corporate Strategy in Organizations', Organization Studies 12(2): 251-73.

Laine, Pikka-Maaria and Vaara, Eero (2007) 'Struggling Over Subjectivity: A Discursive Analysis of Strategic Development in an Engineering Group', Human Relations 60(1): 29-58.

Levy, David L., Alvesson, Mats and Willmott, Hugh (2003) 'Critical Approaches to Strategic Management', in M. Alvesson and H. Willmott (eds) Studying Management Critically, pp. 92110. London: Sage.

Lilley, Simon (2001) 'The Language of Strategy', in R. Westwood and S. Linstead (eds) The Language of Organization, pp. 66-88. London: Sage. 
Luke, Allan (2002) 'Beyond Science and Ideology Critique: Developments in Critical Discourse Analysis', Annual Review of Applied Linguistics 22: 96-110.

Lyons, John (1977) Semantics 2. Cambridge: Cambridge University Press.

Mantere, Saku and Vaara, Eero (2008) 'On the Problem of Participation in Strategy: A Critical Discursive Perspective’, Organization Science 19(2): 341-61.

McCabe, Darren (2010) 'Strategy-as-Power: Ambiguity, Contradiction and the Exercise of Power in a UK Building Society', Organization, in press.

Norton, Todd and Sadler, Chris (2006) 'Dialectical Hegemony and the Enactment of Contradictory Definitions in a Rural Community Planning Process', Southern Communication Journal 71(4): 363-82.

Oakes, Leslie S., Townley, Barbara and Cooper, David J. (1998) 'Business Planning as Pedagogy: Language and Control in a Changing Institutional Field', Administrative Science Quarterly 43(2): 257-92.

Phillips, Nelson, Sewell, Graham and Jaynes, Steve (2008) 'Applying Critical Discourse Analysis in Strategic Management Research’, Organizational Research Methods 11(4): 770-89.

Rakow, Lana F., Belter, Becky, Dyrstad, Heidi, Hallsten, Jodi, Johnson, Jay and Indvik, Keri (2003) 'The Talk of Movers and Shakers: Class Conflict in the Making of a Community Disaster', Southern Communication Journal 69(1): 37-50.

Robichaud, Daniel (2006) 'Steps Toward a Relational View of Agency', in F. Cooren, J. R. Taylor, E. J. Van Every (eds) Communication as Organizing: Empirical and Theoretical Explorations in the Dynamic of Text and Conversation, pp. 101-14. Mahwah, NJ: Lawrence Erlbaum.

Rouillard, Christian and Giroux, Dalie (2005) 'Public Administration and the Managerial Fervour for Values and Ethics: Of Collective Confusion in Control Societies', Administrative Theory and Praxis 27(2): 330-57.

Samra-Fredericks, Dalvir (2003) 'Strategizing as Lived Experience and Strategists' Everyday Efforts to Shape Strategic Direction', Journal of Management Studies 40(1): 141-74.

Samra-Fredericks, Dalvir (2004) 'Managerial Elites Making Rhetorical and Linguistic "Moves" for a Moving (Emotional) Display’, Human Relations 57(9): 1103-44.

Samra-Fredericks, Dalvir (2005) 'Strategic Practice, "Discourse" and the Everyday International Constitution of "Power Effects", Organization 12(6): 803-41.

Seidl, David (2007) 'General Strategy Concepts and the Ecology of Strategy Discourses: A Systemic-Discursive Perspective', Organization Studies 28(2): 197-218.

Swales, John M. (1990) Genre Analysis: English in Academic Settings. Cambridge: Cambridge University Press.

Thomas, Pete (2003) 'The Recontextualization of Management: A Discourse-Based Approach to Analyzing the Development of Management Thinking', Journal of Management Studies 40(4): 775-801.

Thomas, Robyn and Davies, Anette (2005) 'Theorizing the Micro-Politics of Resistance: New Public Management and Managerial Identities in the UK Public Services', Organization Studies 26(5): 683-706. 
at Hanken School of Economics on December 15, 2010 org.sagepub.com Downloaded from 702 Organization 17(6)

Vaara, Eero, Kleymann, Birgit and Seristö, Hannu (2004) 'Strategies as Discursive Constructions: The Case of Airline Alliances', Journal of Management Studies 41(1): 1-35.

van Dijk, Teun A. (1998) Ideology: A Multidisciplinary Approach. London: Sage.

van Dijk, Teun A. (2001) 'Critical Discourse Analysis', in D. Schiffrin, D. Tannen and H.

Hamilton (eds) Handbook of Discourse Analysis, pp. 352-71. Oxford: Blackwell.

Whittington, Richard (2006) 'Completing the Practice Turn in Strategy Research', Organization Studies 27(5): 613-34.

Wodak, Ruth (2004) 'Critical Discourse Analysis', in C. Seale, G. Gobo, J. F. Gubrium and D. Silverman (eds) Qualitative Research Practice, pp. 197-213. London, Sage.

Eero Vaara is Professor of Management and Organization at Hanken School of Economics in Helsinki, Finland and Permanent Visiting Professor at EM Lyon Business School, France. He is also the Chair of EGOS (European Group for Organizational Studies). His research interests focus on strategy and strategizing, organizational change, multinational corporations and globalization, the role of the media in organizing and management and methodological issues in organization and management research. He has recently worked with a particular focus on narrative and discursive perspectives. His work has been published in leading academic journals. Address: Hanken School of Economics, PB 479, 00101 Helsinki, Finland. [eero.vaara@hanken.fi] 